UDC 539.377:624.074.433

A.A. Kozhukhar, Master,

P.O. Bilous, $\mathrm{PhD}$, Assoc.Prof.

Odessa National Polytechnic University, 1 Shevchenko Ave., 65044 Odessa, Ukraine; e-mail: aml28@mail.ru

\title{
PRACTICAL METHODS OF CALCULATING THE AUTOCLAVES' THERMAL STRESSES AT BUILDING INDUSTRY
}

А.А. Кожухар, П.О. Білоус. Практична методика розрахунку температурних напружень у корпусах автоклавів будівельної індустрії. Робота присвячена створенню спрощеної методики розрахунку напружень, які виникають в корпусі автоклава у разі нелінійного розподілу температурного поля за висотою в його поперечного перерізі. Для температурного поля автоклавів використано кусково-лінійну функцію, яка максимально відповідає експериментальним результатам. На підставі гіпотези плоских перерізів отримано вираз для температурних напружень. Виконано аналіз їх розподілу по висоті корпусу автоклава. Тестовий приклад підтвердив достатню ефективність поданої методики щодо інженерних застосувань.

Ключові слова: автоклав, температурний перепад, рівень конденсату, температурні напруження.

A.A. Kozhukhar, P.O. Bilous. Practical methods of calculating the autoclaves' thermal stresses at building industry. The study is devoted to elaboration of a simplified method for calculation of stresses arising in the autoclaves' casing in the case of nonlinear distribution of temperature field on its cross section height. The piece-nonlinear function is applied to the temperature field of autoclaves as maximally corresponding to experimental results. On the basis of flat sections hypothesis an expression for temperature stresses is obtained. The analysis of their distribution by the autoclave casing height is made. The control test confirmed a sufficient efficiency of the offered method for engineering needs.

Keywords: autoclave, temperature difference, condensate level, thermal stresses.

Introduction. While brick and various building structures accelerated thermal processing with humidity treatment used are such devices as the steam chambers or autoclaves. Such chamber body represents a thin-walled cylindrical shell fitted with one (dead-end autoclave) or two (transition autoclave) lids designed for resisting both high internal steam pressure and significant power loads. All pressurized chambers are based on end-bearing and intermediate supports. At the operating autoclave always held is the temperature difference between its casing's cylindrical shell top and bottom sections. Generally, the lower section temperature during the chamber operation is less than the temperature of the upper generatrix section. Due to that difference at the bottom accumulated are the treatment process products and the condensed steam. The chamber body is therefore prone to thermal stresses.

The temperature field mode imposes study of its impact on the autoclave's overall stress-strain state. Respective thermal stresses, superimposed on the stresses due to internal pressure and the local power loads (from the weight of the processed pieces bearing trolleys train, as well as the autoclave and auxiliary machinery bodies weight), can cause stress exceeding the allowed tolerances. Therefore, to ensure a reliable and durable autoclaves' operation necessary is a proper assessment of the value of thermal stress from the actual temperature field distribution on its body cross-section.

Literature review. A comprehensive analytical study of thermal stresses arising at cases of pressurized chambers used by the building materials industry is exposed at [1]. Its results' implementation requires applying numerical methods with respective software products use. The analysis of such stress approximate estimation therein represented demonstrates that these methods are based on largely approximated principles of temperature distribution over the cross-sectional height of the chamber

DOI 10.15276/opu.2.46.2015.09

(C) 2015 The Authors. This is an open access article under the CC BY license (http://creativecommons.org/licenses/by/4.0/). 
casing. In this context, we adopted for our study such distribution principle maximally close to the real situation thus eliminating the need for a complex calculations' algorithm.

The Aim of the Research consists in the creation of a practical engineering method for the construction industry autoclaves' bodies temperature stress calculating. This is due to the fact that in practice when pressurized chambers body designing, often necessary is to estimate the thermal stress properly not involving the PC-aided calculation, to get results considering such casing as a thin-walled cylindrical shell.

Main Body. Since the non-uniform temperature distribution along the autoclave cross-section height the rising takes place from the intermediate supports, similarly to studies $[1,2]$, we consider the casing as a cylindrical shell of length $L$, radius $R$ and thickness $h$, supported only at the front edges' end supports (Fig. 1).

Generally accepted is that at construction industry pressurized chambers use the temperature field distribution is following: along the housing's longitudinal axis $x$, the heating temperature $T$ remains constant, and lengthwise the axis $y$ (Fig. 1) from the upper generatrix to the condensate mirror (height $H$ ) it decreases from $T_{3}$ to a value $T_{2}$, and then abruptly drops to the $T_{1}$ value. The tem-
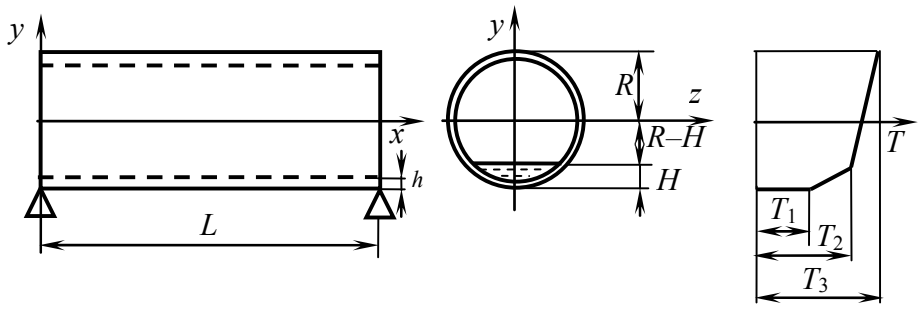

Fig. 1. The autoclave design scheme (a) and the temperature diagram of its body heating over cross-sectional height (b) perature variations by the body thickness and its convective heat exchange with contacting media are usually neglected.

In this regard, the temperature change along the casing's cross-sectional height shall be considered as a piecewise linear function, which equation, according to Fig. 1, is:

$$
T(y)=\left\{\begin{array}{l}
T_{1}+\frac{T_{2}-T_{1}}{H}(R+y), \quad-R \leq y \leq-R+H ; \\
T_{2}+\frac{T_{3}-T_{2}}{2 R-H}(R-H+y), \quad-R+H \leq y \leq R .
\end{array}\right.
$$

Since none external transverse loads present, the bending of a cylindrical shell-beam corresponding to the chamber body can be considered clean. Then, thermal deformation taking place, its cross sections remain plane and normal to the curved beam axis (flat sections hypothesis), only normal stress $\sigma_{x}$ appearing at these sections. In this case, the longitudinal deformation holds a linear relationship

$$
\varepsilon_{x}=a+b y,
$$

where $a, b-$ represent some constants.

According to Hooke's law, taking into account the temperature component, this deformation [3]

$$
\varepsilon_{x}=\frac{\sigma_{x}}{E}+\alpha_{T} T(y),
$$

where $\alpha_{T}$ - coefficient of the casing material linear thermal expansion;

$E$ - this material's elasticity modulus of $1^{\text {st }}$ kind.

Respective stress

$$
\sigma_{x}=E\left[\varepsilon_{x}-\alpha_{T} T(y)\right]=E\left[a+b y-\alpha_{T} T(y)\right] .
$$

In the absence of external loads, for longitudinal force and bending moment valid will be

$$
N_{x}=\int_{F} \sigma_{x} d F=0 ; \quad M_{z}=\int_{F} y \sigma_{x} d F=0,
$$

where $F=2 \pi R h$ - area of the casing cross-section. 
Assigning the (1) dependency to the expression (2)

$$
a=\alpha_{T} \frac{F_{T}}{F} ; \quad b=\alpha_{T} \frac{I_{T}}{I},
$$

where $F_{T}=\int_{F} T(y) d F$;

$$
I_{T}=\int_{F} y T(y) d F
$$

$I$ - axial moment of inertia of the casing cross-section:

$$
I=\pi R^{3} h .
$$

The parameters $F_{T}$ can $I_{T}$ be respectively identified as the thermal force and thermal moment. Assigning constants (3) to the dependency (1) we obtain normal stresses

$$
\sigma_{x}=\alpha_{T} E\left(\frac{F_{T}}{F}+\frac{I_{T}}{I} y\right)-\alpha_{T} E T(y) .
$$

The equation (4) is suitable for stress analysis, the values of temperature $T_{1}, T_{2}, T_{3}$ and $F_{T}$ and $I_{T}$ integrals being known. Calculating these latter we must divide the interval $[-R, R]$ of variable $y$ changes into two intervals $[-R,-R+H]$ and $[-R+H, R]$, corresponding to the straight portions of $T(y)$ function changes' diagram; then

$$
\begin{gathered}
F_{T}=2 R h\left[A_{1}\left(0,5 \pi-\alpha_{H}\right)+A_{2}\left(0,5 \pi+\alpha_{H}\right)-\left(B_{1}-B_{2}\right) R \cos \alpha_{H}\right], \\
I_{T}=R^{3} h\left[B_{1}\left(0,5 \pi-\alpha_{H}\right)+B_{2}\left(0,5 \pi+\alpha_{H}\right)-\frac{2\left(A_{1}-A_{2}\right)}{R} \cos \alpha_{H}+\left(B_{1}-B_{2}\right) \sin \alpha_{H} \cos \alpha_{H}\right],
\end{gathered}
$$

where $A_{1}=T_{1}+B_{1} R, \quad A_{2}=T_{2}+B_{2}(R-H)$,

$$
\begin{aligned}
& B_{1}=\frac{T_{2}-T_{1}}{H}, \quad B_{2}=\frac{T_{3}-T_{2}}{2 R-H}, \\
& \alpha_{H}=\arcsin \frac{R-H}{R}, \\
& \cos \alpha_{H}=\frac{\sqrt{2 R H-H^{2}}}{R} .
\end{aligned}
$$

Thermal stresses, corresponding to (4),

$$
\sigma_{x}(y)= \begin{cases}\alpha_{T} E\left[\left(C-A_{1}\right)+\left(D-B_{1}\right) y\right], & -R \leq y \leq-R+H \\ \alpha_{T} E\left[\left(C-A_{2}\right)+\left(D-B_{2}\right) y\right], & -R+H \leq y \leq R\end{cases}
$$

where $C=\frac{A_{2}+A_{1}}{2}+\left(A_{2}-A_{1}\right) \frac{\alpha_{H}}{\pi}+\left(B_{2}-B_{1}\right) \frac{R \cos \alpha_{H}}{\pi}$,

$$
D=\frac{B_{2}+B_{1}}{2}+\left(B_{2}-B_{1}\right) \cdot\left(\frac{\alpha_{H}}{\pi}-\frac{\sin \alpha_{H} \cos \alpha_{H}}{\pi}\right)+\left(A_{2}-A_{1}\right) \frac{2 \cos \alpha_{H}}{\pi R} .
$$

At temperature linear distribution along the casing height

$$
\begin{gathered}
\frac{T_{3}-T_{1}}{T_{2}-T_{1}}=\frac{2 R}{H}, \\
\frac{T_{3}-T_{2}}{T_{2}-T_{1}}=\frac{2 R-H}{H}, \\
B_{2}=B_{1},
\end{gathered}
$$




$$
A_{2}=T_{2}+B_{2}(R-H)=T_{1}+B_{1} R+\left(T_{2}-T_{1}-B_{1} H\right)=A_{1} .
$$

In such a case, according to (5), the temperature stresses $\sigma_{x}$ do not arise.

Thermal stresses at the autoclave body forming a shell of radius $R$, are defined by temperature changes $\Delta T_{\mathrm{I}}=T_{2}-T_{1}, \Delta T_{\mathrm{II}}=T_{3}-T_{2}$, and the condensate level $H$ height.

Results. At the test example of thermal stresses calculation according to the proposed procedure, we consider the serial autoclave AP 12-3,6 $\times 2,7$ with the following parameters: $R=1,8 \mathrm{~m}, h=0,022 \mathrm{~m}$ (housing material steel $15 \mathrm{~K} E=2,1 \cdot 10^{5} \mathrm{MPa}$ and $\alpha_{T}=1,2 \cdot 10^{-5} \mathrm{grad}^{-1}$ ). For such pressurized chamber at $H=0,2 \mathrm{~m}$ corresponding to the experimental data of the All-Union Research Institute of Cement Mechanical Engineering (Tolyatti, Russia), the temperature function graph can be represented by a broken line with the following characteristics: $T_{1}=T(-R)=90^{\circ} \mathrm{C}, \quad T_{2}=T(-R+H)=160{ }^{\circ} \mathrm{C}$, $T_{3}=T(R)=160{ }^{\circ} \mathrm{C}$.

The thermal stresses' values and the calculations results obtained on the basis on the pressurized chamber shell body diagram used in [1], are presented in the table. It can be concluded that the engineering method allows getting results close enough to the values corresponding to this scheme. The smallest differences values are registered for maximum tensile stress at the lowest point of the casing cross-section.

Results of thermal stress calculation for the pressurize chamber AP 12-3,6×2,7

\begin{tabular}{c|c|c}
\hline \multirow{2}{*}{ Hell cross-section point } & \multicolumn{2}{|c}{ Thermal stress $\sigma_{x}, \mathrm{MPa}$} \\
\cline { 2 - 3 } & Engineering methods & Refined accuracy calculation \\
\hline Lowest point & 124 & 141 \\
\hline Point at the condensate level & -49 & -39 \\
\hline Upper point & 17 & 22 \\
\hline
\end{tabular}

The results of stress calculation (5) when condensate level $H=0,2 \mathrm{~m}$ depending onto temperature drop $\Delta T_{\mathrm{I}}$ at $\left(\Delta T_{\mathrm{II}}=0\right)$ are shown at the Fig. 2 , and for the temperature drop $\Delta T_{\mathrm{I}}=70{ }^{\circ} \mathrm{C}\left(\Delta T_{\mathrm{II}}=0\right)$ depending onto $H$ refer to Fig. 3.

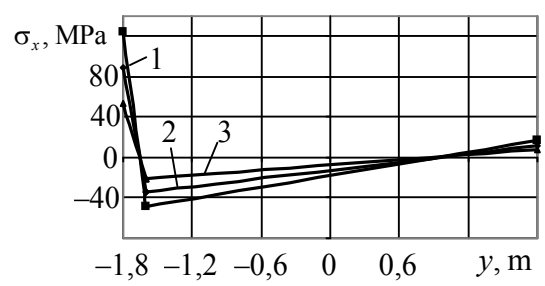

Fig. 2. Temperature stress distribution diagrams at $\Delta T_{I}=70^{\circ} \mathrm{C}(1), \Delta T_{I}=50^{\circ} \mathrm{C}(2), \Delta T_{I}=30^{\circ} \mathrm{C}(3)$

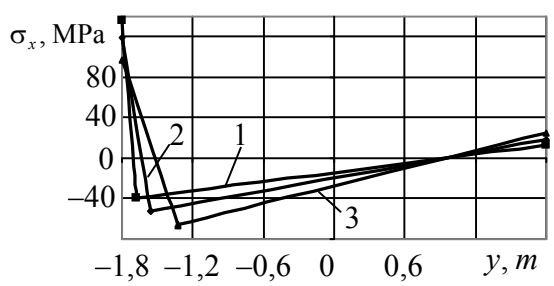

Fig. 3. Temperature stress distribution diagrams at $H=0,12 m(1), H=0,24 m(2), H=0,48 m$ (3)

It is evident that in the lower and upper autoclave casing regions the tensile stress takes place, and in the central region the compressive stresses do act. At the lowest point of the body cross-section the tensile stresses are always maximal. These stresses are reduced along the cross-section height and are replaced by compressive stresses. At the height of the condensate level $H$ they are maximized. Further, they drop down being again replaced by tensile stresses in the upper body part but their value is negligible at that.

The temperature $\Delta T_{\mathrm{I}}\left(\Delta T_{\mathrm{II}}=0\right)$ difference decrease the reduction of both the maximum tensile and maximum compressive stress (Fig. 2) takes place. Increase in the level of condensate $H$ leads to the maximum tensile stress reduction and increase in the maximum compressive stress (Fig. 3).

Conclusions. These results indicate that the maximum tensile thermal stresses values, necessary for autoclaves' body strength evaluation in terms of their crack resistance can be determined according to the proposed approximate method with sufficient accuracy for engineering applications. 


\section{Література}

1. Кожухарь, А.А. Оценка температурных напряжений в корпусах автоклавов стройиндустрии / А.А. Кожухарь, В.А. Белоус, П.А. Белоус // Тр. Одес. политехн. ун-та. — 2009. — Вып. 2(32). C. $27-30$.

2. Кожухарь, А.А. Моделирование напряженно-деформированного состояния корпуса автоклава при комбинированной нагрузке / А.А. Кожухарь // Моделирование в прикладных научных исследованиях: Материалы XVIII семинара / под ред. В.П. Малахова и др. — Одесса: ОНПУ, 2010. C. $81-82$.

3. Barron, R.F. Design for Thermal Stresses / R.F. Barron, B.R. Barron. — Hoboken, N.J.: Wiley, 2012. $510 \mathrm{p}$.

\section{References}

1. Kozhukhar, A.A., Belous, V.A. and Belous, P.A. (2009). Estimation of temperature stresses in bodies of autoclaves of building industry. Odes 'kyi Politechnichnyi Universytet. Pratsi, 2, 27-30.

2. Kozhukhar, A.A. (2010). Modeling of stress-strain state of autoclaves shell under combined loads. In V.P. Malakhov (Ed.), Proceedings of $18^{\text {th }}$ Seminar on Modeling in Applied Research (pp. 81-82). Odessa: Odessa National Polytechnic University.

3. Barron, R.F. and Barron, B.R. (2012). Design for Thermal Stresses. Hoboken, N.J.: Wiley. 